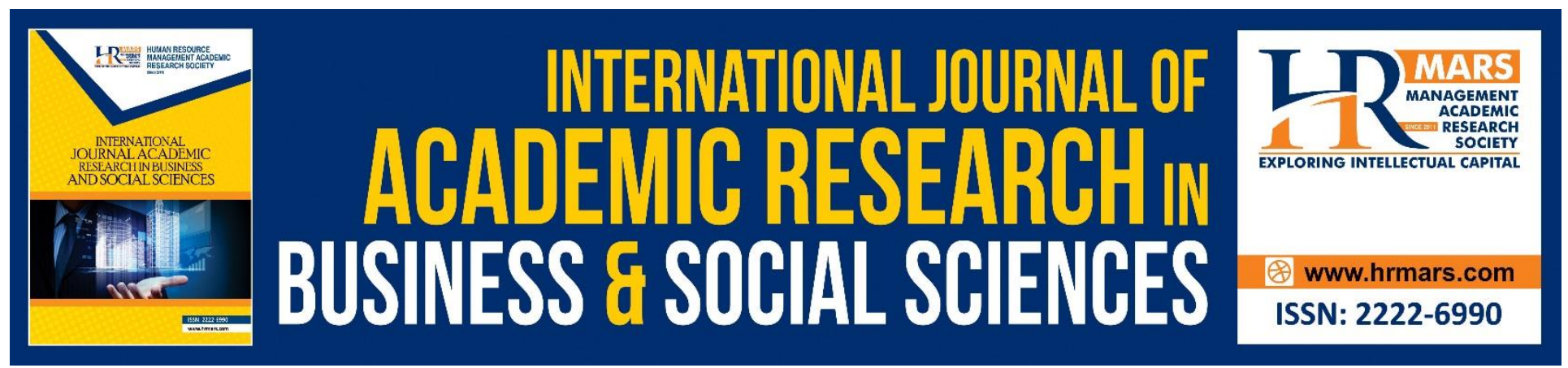

\title{
Effects of Mobile Phone Usage Behavior and Mobile Phone Addiction among Youth
}

Kalaivani A/P Munusamy, Akmar Hayati Ahmad Ghazali

To Link this Article: http://dx.doi.org/10.6007/IJARBSS/v10-i16/8297

DOI:10.6007/IJARBSS/v10-i16/8297

Received: 13 September 2020, Revised: 12 October 2020, Accepted: 30 October 2020

Published Online: 17 November 2020

In-Text Citation: (Munusamy \& Ghazali, 2020)

To Cite this Article: Munusamy, K. A., \& Ghazali, A. H. A. (2020). Effects of Mobile Phone Usage Behavior and Mobile Phone Addiction among Youth. International Journal of Academic Research in Business and Social Sciences, 10(16), 134-145.

Copyright: (c) 2020 The Author(s)

Published by Human Resource Management Academic Research Society (www.hrmars.com)

This article is published under the Creative Commons Attribution (CC BY 4.0) license. Anyone may reproduce, distribute, translate and create derivative works of this article (for both commercial and non-commercial purposes), subject to full attribution to the original publication and authors. The full terms of this license may be seen

at: $\underline{\text { http://creativecommons.org/licences/by/4.0/legalcode }}$

Special Issue: Youth and Community Wellbeing: Issues, Challenges and Opportunities for Empowerment V2, 2020, Pg. 134 - 145

http://hrmars.com/index.php/pages/detail/IJARBSS

JOURNAL HOMEPAGE

Full Terms \& Conditions of access and use can be found at http://hrmars.com/index.php/pages/detail/publication-ethics 


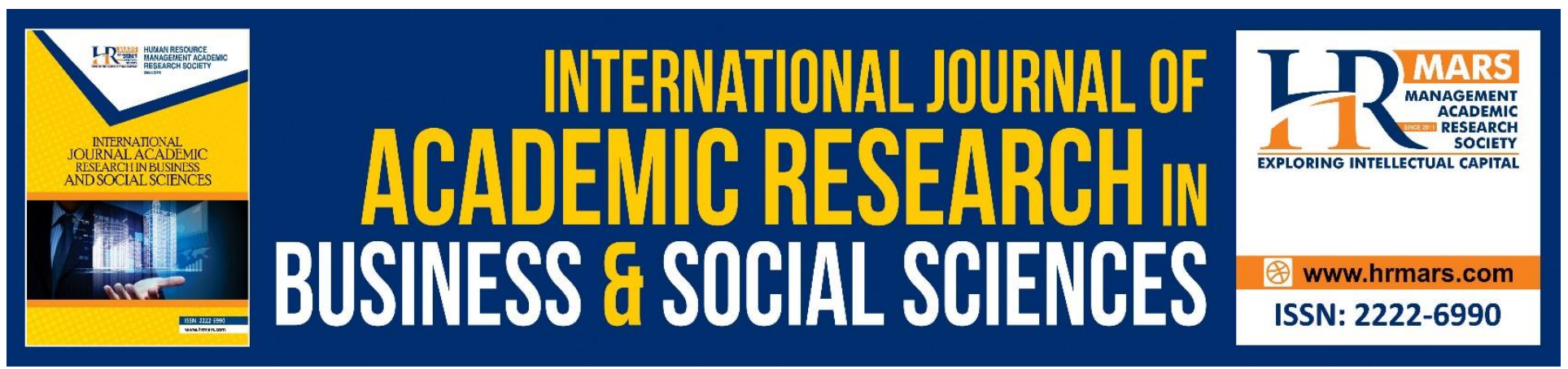

\title{
Effects of Mobile Phone Usage Behavior and Mobile Phone Addiction among Youth
}

\author{
Kalaivani A/P Munusamy, Akmar Hayati Ahmad Ghazali
}

Institute for Social Science Studies, Universiti Putra Malaysia, 43400 Serdang, Selangor, Malaysia

Faculty of Modern Languages and Communication, Universiti Putra Malaysia, 43400 Serdang, Selangor, Malaysia

Email: ani_vani88@yahoo.com,akmar@upm.edu.my

\begin{abstract}
Mobile phone offers several benefits which ease community socializing and communication process. Moreover, mobile phone assists them in information and entertainment seeking process while at the same time act as safety tool during emergency situation. Nevertheless, albeit benefit offered, mobile phone has created problem to the community particularly to the young one whereby addiction is most obvious one. Such social issue however, seems to attract less internet from the scholars, which eventually lead to lack of understanding on this issue. Consequently, in addiction to this, the present research aims to investigate one of the significant areas of mobile phone usage to analyze the psychological context and the relationships for young users between mobile phone addiction and mobile phone usage. Based on this problems, this study was conducted to determine the level of mobile phone usage among youths; and to find out the level of the mobile phone addiction among youths. The research was carried out on 400 youths in Klang Valley using the survey method. The finding concludes that youths mobile phone usage behavior and addiction in moderate level. A serious attention must give to this issue before the youths addicted highly. All the responsible parties such as parents, educators and policy makers must work together to combat the negative impact of mobile phone addiction.
\end{abstract}

Keywords: Youth, Mobile Phone, Addiction and Mobile Phone Usage Behavior

\section{Introduction}

Mobile phone classified as device that used for information searching, communication, entertainment, online transaction and so on (Adams \& Paul, 2017). In addition, the mobile phone is seen as an essential means of communication and has become an essential part of the society. It is not unprecedented because the new generations are digitally literate (i.e. citizens of modern age) and would naturally be easily drawn to any new gadget. On today's world mobile phones became as a basic need to people and no more categorized as luxury items (Fadzil, Ghazali, Samah \& Bolong, 2019). 
The millennials not only used the mobile phone as a communication tool but also as a way of expressing themselves (Ito \& Okabe, 2004) and, very specifically, as a means of looking stylish and trendy (Ling 2001). It been contrasted to earlier generations, or known as early immigrants (i.e. people born before the technological era), that frequently utilized their cell phones for communication purpose or for contact the customers in business (Bianchi \& Phillips, 2005).

Development of mobile phone technology has created a valuable range of role and enhanced movability where been expanded the pervasiveness use of mobile phone, particularly among adolescents. Moreover, Adams and Paul (2017) asserts the smartphone has appeared as one of the most popular consumer electronic devices among young adults. They also mentioned adolescent customers are increasingly aware of the functions and features of cell phone as opposed to their older peers. Although mobile phones offer great convenience, they can impose adverse effects, trigger dramatic psychological changes and consequences harmful physiological reactions, leading to a condition widely identified as 'cell phone addiction' (Eduardo et al.,2012). It was identified high psychological needs satisfaction is strongly correlated with physical and psychological wellbeing, while low psychological needs can cause physical and psychological issues, including addictive behaviors such as internet addiction and cell phone addiction (Kumcagiz \& Gunduz, 2016; Settley, 2020).

Findings of past study revealed teenagers who were exhibit lower level of psychological security depend on cell phones as a way of getting attached with others also contribute to the mobile phone attachment risk (Kim, 2018; Alamassi et al., 2015). Those results are consistent with the theory of self-determination, a motivational paradigm that explains how individual motivation is produced and then influences the development of humans. Additionally, this study indicates that one social context exists in the presence of long-term psychological needs, the person may have a significant desire to fulfill those expectations in other social contexts, such as the virtual Internet world (Ryan \& Deci, 2020).

The above implies that satisfaction with psychological wants is not only a part of the social context, but also an internal motivation that triggered people to exhibit externalizing behavior. Hence, it suggests that the fulfillment of psychological needs of teenagers can satisfy their inner void and solitude by playing computer games, watching videos in online or chatting in online (Sheldon, Abad \& Hinsch, 2011).

\section{Problem of Statement}

In previous studies there were found that usage of mobile phone more than one hour per day would cause the health issues, poor memory and concentration deficit Sandstrom, Wilen, \& Mild, 2001), whereas another study also supported this statements even there have high tendency psychological impacts for those who spend more than seven hours a day in using mobile phone (Fredrik, Michael, \& Lennart, 2008). Furthermore, Thomee, Harenstam, and Hagberg (2011) supported that statement and his study also indicated repeated use of the mobile phone is correlated with depression, sleep problems and physical symptoms.

Past studies found obsessive mobile phone use could carry into mental illness (Beranuy et al., 2009, Lee et al., 2014), and over utilization of mobile phones will cause a big problem among adolescents such as loneliness, drug and alcohol use, mental depression and poor performance in academic (Sánchez-Martínez \& Otero, 2009). Moreover, Liu and Yoo (2018) asserts the most 
immediate effect on college students was that the higher degree of cell phone use fascinated the drop in their educational achievements and it can quickly distract students during learning process in classroom (Ravizza Hambrick \& Fenn, 2014). In summary, dependent on the mobile phone can have a negative effect to the mental illness and social health of an individual also effect on the everyday activities, resulting in encountered to discover mobile phone addiction among university students, as well as identify potential addiction factors.

\section{Research Objective}

The general objective of this study is to examine the effect mobile phone addiction among youths. Specifically, this paper will determine the level of mobile phone usage among youths; and to find out the level of the mobile phone addiction among youths.

\section{Literature Review}

\section{Mobile Phone Usage Behavior}

Researchers noticed adolescent cell phone users continue to demonstrate sufficient monthly spending. Mobile phones are designed multiple features that allow its young users to communicate and for entertainment. Recent study demonstrated text messaging to be the common feature used by young users (Nurvitadi, 2003; Madell \& Muncer, 2004). Teenagers made text messaging a necessity due to the service was fast, inexpensive and easy (Grinter \& Eldrige, 2001). Eldrige and Grinter (2001), projected adolescents would use text messaging to schedule time for talking, changing plans that already made, and talking or chattering.

This is in line with Lie (2004), statement that text messaging patterns it has a substantial peak among teenagers significantly between the ages of 16 and 24. In Nurvitadhi (2003), studies of teenage cell phone use in Japan and the USA, found that a large proportion (69.53\%) of Japanese adolescents have chosen to use the text messaging service. Whereas American teenagers (35.5\%) preferred cell phone game applications. More MP3 (MPEG-1 Audio Layer 3) features of cell phones were also found to be used by Japanese adolescents $(40.21 \%)$ compared with other features. In his study on female teenagers and young adult men, Ling (2001) found that female teenagers sent more text messages compared to adult men. He also noted that there are transition period periods in mobile phone usage patterns among teenagers. While the teenagers in the early 20s, text messaging was to ever be phased out by voice calling.

In line with Ling's results, Lie (2004) identified some trend exists among young adults in mobile voice telephony. A research analyzing cell phone usage habits among high school students found similar results (Madell \& Muncer, 2004). A majority (91.9\%) of a total of 1340 students send text messages (89.4\%) and receiving phone calls (80\%) using their mobile phones. The findings appear to indicate a slightly greater preference for conventional call functions among younger samples than for the SMS system.

Other than that, there were have a positive indication of mobile phone usage behavior. Some researchers seen mobile phone have significant relationship in make the relationship stronger where believed mobile phone constructed to let family members and peers communicate. Past studies show rather than friends' youths also contact their family members. It's really important for teenagers to be able to reach parents easily and vice versa (Australian Psychological Society, 2004), because it allows them to feeling secure and associated with important people in their lives. Rather than that, 
this is really play a vital role in emergency time. Generally speaking, cell phones help establish family relationships by preserving clear communication and reducing human interaction (Wale \& Gillard, 1994). Adolescents and their families can connect at all times and in all locations without much difficulty via mobile phone. Both teenagers and their families may be in close contact with each other. They both addressed contacting friends frequently to talk, exchange stories and gossip. Thereby the mobile phone provides a chance to establish and preserve their connection with people. Consequently, mobile phone gives us an opportunity to establish and sustain human relationships.

\section{Mobile Phone Usage Behavior and Mobile Phone Addiction}

In past study, Choliz (2010); and Gao et al., (2018) mentioned mobile phone addiction is referred to as mobile phone dependency (Choliz, 2010, Gao et al., 2018), or problematic use of mobile phone (Liu et al., 2017). While the evidence of cell phone addiction is still under debate for being a kind of mental addictions (Billieux et al., 2015), many scholars tend to view it as a behavioral addiction. Thus, Niemsz, Griffiths and Banyard (2005); and Yen et al., (2009), defined typical addictive behaviors such as cognitive salience, loss of control, mood change, tolerance, withdrawal, conflict and relapse as mobile phone addictions. Medical norm for cell phone dependency is expressly reinterpreted who identified and treated certain dependence habits for example drug consumptions and gambling requirements outlined in the updated fourth edition of the Diagnostic and Statistical Manual of Mental Disorders (Billieux et al., 2015).

Mobile phone use is a part of interactive technology such as internet, and it is anticipated to have similar impact. This research explores the purposes that higher mobile phone usage will result in increased addiction to the mobile phone and associated problems. Past studies have viewed the total of received calls and messages as the main contribution to the mobile phone addiction (Billieux et al., 2008). Nowadays, received calls and numbers of sending messages were used to examine the mobile phone usage behavior among individuals (Billieux et al., 2007). Nevertheless, it is clear that both factors not correlate on the addiction towards mobile phone (Walsh et al., 2011) and therefore the present research has accentuated on necessity to include research on connection with mobile phone use and mobile phone addiction in order to explain the mediation process mobile use.

In order to identify the problematic sensation of mobile phone utilization Billieuex, et al., (2015), suggested a model involving three distinct mechanisms for developing problematic mobile phone use. The excessively affirmation pathway focuses on personality traits such as low self-esteem, emotional instability, anxiety, and unstable attachments which can cause the individual to use mobile phones excessively as a way to try and receive reassurance from others. Addiction to the mobile phone would have difficulty in emotional understanding which can lead to more interpersonal issues. Those people who more dependent on mobile phones or any other media, are more like to hide their feelings and cover up them. The theory of compensatory Internet use also suggests that negative life circumstances might rise a motivation to go online to alleviate negative feelings (Kardefelt-Winther, 2014b). When the motivation to go online is focused on an unsatisfied need for real life and the use of the Internet helps relieve the real-life problem, then an person may express a greater desire to spend more time online, that could lead to undesirable results (Kardefelt-Winther, 2014a). 


\section{Mobile Phone Addiction and Consequences}

Past studies showed addictive cell phone use may lead to significant problems in students' sleep habits (Van den Bulck, 2003). Furthermore, as stated by Liu et al., (2018) mobile phone dependency has become a worldwide concern due to its rapid growth in usage and its negative impacts. This is in line with Kamibeppu and Sugiura (2005), who mentioned students tend to engage in emails and texts and feel anxious even during the night when they are supposed to sleep because they have not received replies from friends. Apparently, the addictive condition leads students remain awake all nights, thereby impeding their daily activities. In addition, Beranuy, Oberst, Carbonell and Chamarro, (2009) studies also stated psychological distress, sleep disorder (Liu et al., 2017), and less academic achievements can result from mobile phone addiction(Samaha \& Hawi, 2016). Hence, for many young adults, cell phones are absolutely essential, but these devices can adversely affect their mental health and wellbeing. Even though the mobile phone usage driven to better access to information, improved accessibility and many conveniences but still brought many threats because of improper use of smartphones (Adams \& Paul, 2017).

Generally, there have two ways to identify the mobile phone addiction. First, ascertain whether certain amount of frequency of mobile phone usage is higher than limit that set. Second, evaluate the frequent use of mobile phones has a detrimental effect on physical, psychological and mental health. If the person meets both criteria, the user with a mobile phone addiction can be identified (Jiang \& Bai, 2014). A possible cell phone user is characterized by more than four hours per day. Even though mobile phones are useful for humans, their detrimental effect is becoming more apparent. University students with mobile phone dependency have poor ability to monitor (Wang et al., 2016). They could allocate a lot of time "interacting" with the mobile phone, reducing the time required to perform the duties of their everyday lives. According to Çagan et al., (2014), the greater the intensity of cell phone addiction, the more likely the academic performance of university students would decrease. Thus, the mobile phone addiction can be classified as secretive disease that's affecting many phone users. This is in line with Kim, Milne and Bahl (2018), who mentioned it is essential to give an attention in understanding the disregard behavior which result in negative and psychological experiences in health and impact the quality of life.

\section{Result and Discussion}

\section{Socio-Demographic Profiles of the Respondents}

There were 400 respondents who took part in this study and the result of respondent's sociodemographic profiles is shown in Table 1.1. The result revealed that majority of the respondents were male $(63.5 \%)$ and the remaining were female (34.5\%). The result also indicates that most of the respondents involved are 21 years old and younger (66\%) and $34 \%$ of the respondents are less than 20 years old. Thus, Muhammud (2012) asserted teenagers aged 16 years old and above are more abstract and think critically to make decisions. Therefore, this group of teenagers are more mature and can start making wise decisions in their life. 
Table 1.1: Socio-Demographic Profiles of Respondents $(n=400)$

\begin{tabular}{lll}
\hline \hline Profile & Frequency & Percentage (\%) \\
\hline Gender & & \\
Male & 254 & 63.5 \\
$\quad$ Female & 138 & 34.5 \\
Age & & \\
21 years old and older & 136 & 66.0 \\
20 years old and younger & 264 & 34.0 \\
Ethnic & & \\
Malay & 317 & 79.3 \\
Chinese & 45 & 11.3 \\
Indian & 12 & 3.0 \\
Sarawakian & 12 & 3.0 \\
Sabahan & 11 & 2.8 \\
Others & 3 & 0.8 \\
\hline \hline
\end{tabular}

\section{Mobile Phone Usage Behavior}

Mobile phone usage belongs to some interactive technology as the internet, and is expected to produce a similar impact. Past studies have viewed on total phone-talk time, ad the number of calls and text messages as the main contributor towards mobile phone addiction (Billieux et al., 2007, Billieux et al., 2008). The present study identified the needs of mobile phone usage in youth's daily routine. Respondent's mobile phone usage behavior level was categorised into three categories namely low (mean score 1.00-2.33), moderate (mean score 2.34- 3.67) and high (mean score 3.685.00) (Table 1.2). The statements were arranged according to the mean score, from the highest to the lowest. A mean score above 3.68 showed that respondents in the study have a strongly addicted with mobile phone. The lower level of mean score stated that youths mobile phone usage is very less, followed by moderate level which showed that youths was moderately used mobile phone and high level stated that youth behaviour was very high in mobile addiction.

Table 1.2: Mobile Phone Usage Behaviour Level Score Scale

\begin{tabular}{lc}
\hline \hline Level & Scores \\
\hline Low & $1.00-2.33$ \\
Moderate & $2.34-3.67$ \\
High & $3.68-5.00$ \\
\hline
\end{tabular}

Table 1.3 showed mean score and standard deviation of statements related to mobile phone usage behavior. This section consists 11 items regarding different types usage of mobile phone to calculate each respondent's usage level in their daily routine. The respondents answered based on the needs mobile phone usage and the items were measured using the Likert scale. They are as follows: 1= never use; 2 =almost never; 3 = occasionally/sometimes; $4=$ =almost every time and 5=frequently use. All the statements related to mobile phone usage behaviour were measured based on mean scores. 
INTERNATIONAL JOURNAL OF ACADEMIC RESEARCH IN BUSINESS AND SOCIAL SCIENCES

Vol. 10, No. 16, Youth and Community Wellbeing: Issues, Challenges and Opportunities for Empowerment V2. 2020, E-ISSN: 2222-6990 @ 2020 HRMARS

Table 1.3: Mean Score of Statements on Respondents' Mobile Phone Usage Behavior $(n=400)$

\begin{tabular}{|c|c|c|c|c|c|}
\hline & \multicolumn{2}{|l|}{ Statement } & \multirow[t]{2}{*}{ an } & \multicolumn{2}{|c|}{ SD } \\
\hline 1. & Using for chatting (e.g. WhatsApp) & 4.71 & & 0.760 & \\
\hline 2. & Browsing information in the internet & 4.71 & & 0.703 & \\
\hline 3. & \multicolumn{2}{|c|}{ Using to connect with social networking sites } & 4.65 & & 0.758 \\
\hline 4. & \multicolumn{2}{|l|}{ Use phone for taking pictures } & 4.06 & 1.013 & \\
\hline 5. & \multicolumn{2}{|l|}{ Receiving phone calls } & 3.62 & 1.197 & \\
\hline 6. & \multicolumn{2}{|l|}{ Taking selfie } & 3.42 & 1.205 & \\
\hline 7. & \multicolumn{2}{|l|}{ Playing games } & 3.30 & 1.386 & \\
\hline 8. & \multicolumn{2}{|l|}{ Use for navigation such as Waze } & 2.97 & 1.201 & \\
\hline 9. & \multicolumn{2}{|l|}{ Use for keep health records } & 2.63 & 1.167 & \\
\hline 10. & \multicolumn{2}{|l|}{ Sending SMS (Short Message Service) } & 2.28 & 1.185 & \\
\hline 11. & \multicolumn{2}{|c|}{ Sending MMS (Multimedia Messaging Service) } & 1.76 & 1.198 & \\
\hline
\end{tabular}

Overall Mean Score: 3.45

* Note: $1.00-2.33=$ Low, $2.34-3.67=$ Moderate, $3.68-5.00=$ High

The results showed there have few purposes in using mobile phone. Highest mean score 4.71 gained for the two items were respondents answered they are more frequently use mobile phone for chatting (e.g. WhatsApp) and browsing information in the internet. This is in line with Kaufmann and Peil (2020), who mentioned online communication has become a global phenomenon and it is shifted to smartphone usage since traditional Short Message Service (SMS) system is gradually replacing the communication platforms.

Moreover, WhatsApp, a free-of- charge, advertising-free apps are more frequently used by people in 180 countries (WhatsApp, 2019). However, the results indicated lowest mean score 1.76 for statement sending MMS (Multimedia Messaging Service). Overall, the level of the mobile phone usage is in moderate level with mean score 3.45. The results showed the youths not heavily influence with mobile phone, however there have a mild impact in their daily life.

\section{Mobile Phone Addiction}

The use of mobile phones is a part of interactive technology such as internet, and it is anticipated to have similar impact. This research explores the hypothesis that higher mobile phone usage will result in increased addiction to the mobile phone and associated problems. The statement to measure respondents' mobile phone usage addiction level was developed based on past literatures.

Table 1.4 consisted of 10 statements to discuss about the level of mobile phone addiction. Each of the statements was measured in the form of Likert Scale of 1 to 5. Scale 1 (strongly disagree), Scale 2 (disagree), Scale 3 (somewhat agree), Scale 4 (agree) and Scale 5 (strongly agree). All the statements related to addiction were measured based on mean scores. For each statement, a score was given based on the answer. For example, if the respondents agreed of those statements, they will answer "strongly agree" and if they did not agree with those statements, they will state "strongly disagree". The score recorded where the reversed scale scores. 
The researcher used mean score levels namely low, moderate and high to categorise those levels. Based on 10 statements given, the possible mean scores from 3.68 to 5.00 indicated very high addiction on mobile phon. This is followed by mean score 2.34 to 3.67 which stated that the level of addiction toward mobile phone were moderate. Lastly, mean score from 1 to 2.33 stated that the level of addiction towards mobile phone was very low. The results of mean ranking are shown in Table 1.4.

Table 1.4: Mobile Phone Addiction Level Score Scale

\begin{tabular}{ll}
\hline \hline Level & Scores \\
\hline Low & $1.00-2.33$ \\
Moderate & $2.34-3.67$ \\
High & $3.68-5.00$ \\
\hline \hline
\end{tabular}

The results revealed that level mobile phone addiction was moderate (mean score 3.34) (Table 1.5). The result indicated that youths mobile phone usage addiction may impact their daily life. The statements were arranged according to the mean score, from the highest to the lowest.

Table 1.5: Mean Score of Statements on Respondents' Mobile Phone addiction $(n=400)$

\begin{tabular}{lll}
\hline \hline Statement & *Mean & SD \\
\hline 1. Using my smartphone longer than I had intended & 4.02 & 1.369 \\
2. $\begin{array}{l}\text { Constantly checking my smartphone so as not to miss conversations } \\
\text { between other people on Twitter or Facebook }\end{array}$ & 3.65 & 1.519
\end{tabular}

3. I felt that I neglected my work due to the heavy use of smartphones $\quad 3.57$

4. Won't be able to stand not having a smartphone 3.52

5. I will never give up using my smartphone even when my daily life is 3.43 already greatly affected by it

6. Having a hard time concentrating in class, while doing assignments, or 3.28 while working due to the use of smartphone

7. Feeling impatient and fretful when I am not holding my smartphone 3.13

8. Always thinking of using my smartphone even though I am not using it 3.02 at the current stage/ at the moment? when I am not using it

9. Feeling pain in the wrists or at the back of the neck while using a 2.97 smartphone

10. The people around me tell me that I use my smartphone too much. $\quad 2.79$ 
All the respondents stated that they moderately addicted towards mobile phone addiction. Thus, the results showed the have moderate relationship between mobile phone usage behavior and addiction. Based on Hussain, Williams and Griffiths (2015), addiction perceived as repetitive habit pattern that increases the risk of disease and/or associated personal and social problems. Addictive behaviours are often experienced subjectively as 'loss of control'. In this study, mobile addiction can be understand as behaviour where the youth lost control over usage of mobile phone. They can't control their self from using mobile phone at their side, they become emotionally and physically unstable when they don't have their mobile phone.

\section{Conclusion}

Finding of this the paper revealed there have a positive relationship between mobile phone usage behavior and mobile phone addiction. Therefore, this paper might be useful to educators, and most importantly for youths in understanding about the impact of level of mobile phone usage behavior and the implications of its disproportionate use. Hence, the educators should play the vital role in strengthening the interpersonal relationship building techniques and self-control training among the who showing negative traits, and in planning of study time and endorsing them to achieve their life goals.

In addition, students at universities will understand about the level of mobile phone usage behavior and the implications of its disproportionate use. Parents and those who are responsibility on youth would find out that the experience of this paper has strengthened their knowledge and the ability addition to providing clear guidelines for mobile communication activities for individuals. For the authority parties such as government and policy makers this study could be useful in planning programs for young technology users. In a nutshell, this paper can emphasize the necessity of proper use of technology and provide direction to the technology-savvy youth in particular on how to reap the technology's advantage for their positive growth.

\section{References}

Adams, D., \& Paul, L. (2017). State of the smart Consumer business usage patterns. Global Mobile consumer survey. Deloitte: London.

Alamassi, S. M. S., Al Jneibi, F. S., Al Kaabi, F., Dela Cruz Recio, C. H., El Zaatari, W., \& Panitsides, E. A. (2015). What Hinders Educational Change? School Principals' Perspectives in the UAE Context. Multilingual Academic Journal of Education and Social Sciences, 3(1), 43-59.

Australian Psychological Society, The. (2004). Psychosocial aspects of mobile phone use among students. $\quad$ Retrieved $\quad$ on $10^{\text {th }}$ July 2020 at http://www.psychology.org.au/news/psychology_week/10.10

Beranuy, M., Oberst, U., Carbonell, X., \& Chamarro, A. (2009). Problematic Internet and mobile phone use and clinical symptoms in college students: The role of emotional intelligence. Computers in Human Behavior, 25(5), 1182-1187.

Bianchi, A., \& Phillips, J. G. (2005). Psychological predictors of problem mobile phone use. CyberPsychology \& Behavior, 8(1), 39-51.

Billieux, J., Van der Linden, M., \& Rochat, L. (2008). The role of impulsivity in actual and problematic use of the mobile phone. Applied Cognitive Psychology: The Official Journal of the Society for Applied Research in Memory and Cognition, 22(9), 1195-1210. 
Billieux, J. (2012). Problematic use of the mobile phone: a literature review and a pathway model. Current Psychiatry Reviews, 8(4), 299-307.

Billieuex, J., Maurage, P., Lopez-Fernandez, O., Kuss, D. J., \& Griffiths, M. D. (2015). Can disordered mobile phone use be considered a behavioral addiction? An update on current evidence and a comprehensive model for future research. Current Addiction Reports, 2, 156-162.

Fadzil, M. F., Ghazali, A. H. A., Samah, A. A., \& Bolong, J. (2019). A Systematic Review on Factors Influencing Mobile Phone Addiction among Youths in Asean Countries. International Journal of Academic Research in Business and Social Sciences, 9(3), 1097-1114.

Grinter, R. E., \& Eldridge, M. A. (2001). Y do tngrs luv 2 txt msg?. In Proceedings of the Seventh European Conference on Computer-Supported Cooperative Work ECSCW '01 Bonn, Germany, Edited by: Prinz, W., Jarke, M., Rogers, Y., Schmidt, K. and Wulf, V. 2019 - 238. Dordrecht, Netherlands: Kluwer Academic Publishers.

Hawi, N. S., \& Samaha, M. (2017). Relationships among smartphone addiction, anxiety, and family relations. Behaviour \& Information Technology, 36(10), 1046-1052.

Hussain, Z., Williams, G. A., \& Griffiths, M. D. (2015). An Exploratory Study of the Association between Online Gaming Addiction and Enjoyment Motivations for Playing Massively Multiplayer Online Role-playing Games. Computers in Human Behavior, 50, 221-230.

Kamibeppu, K., \& Sugiura, H. (2005). Impact of the mobile phone on junior high-school students' friendships in the Tokyo metropolitan area. Cyberpsychology \& Behavior, 8(2), 121-130.

Kardefelt-Winther, D. (2014). A conceptual and methodological critique of internet addiction research: Towards a model of compensatory internet use. Computers in Human Behavior, 31, 351-354.

Kardefelt-Winther, D. (2014). Problematizing excessive online gaming and its psychological predictors. Computers in Human Behavior, 31, 118-122.

Kaufmann, K., \& Peil, C. (2020). The mobile instant messaging interview (MIMI): Using WhatsApp to enhance self-reporting and explore media usage in situ. Mobile Media \& Communication, 8(2), 229-246.

Kim, J. H. (2018). Psychological issues and problematic use of smartphone: ADHD's moderating role in the associations among loneliness, need for social assurance, need for immediate connection, and problematic use of smartphone. Computers in Human Behavior, 80, 390-398.

Kim, E., \& Koh, E. (2018). Avoidant attachment and smartphone addiction in college students: The mediating effects of anxiety and self-esteem. Computers in Human Behavior, 84, 264-271.

Kim, K., Milne, G., R., \& Bahl, S. (2018). Smartphone addiction and mindfulness: an intergenerational comparison. International Journal of Pharmaceutical and Healthcare Marketing, 12(1), pp. 2543.

Kumcagiz, H., \& Gunduz, Y. (2016). Relationship between psychological well-being and smartphone addiction of university students. International Journal of Higher Education, 5(4), 144-156.

Madell, D., \& Muncer, S. (2004). Back from the beach but hanging on the telephone? English adolescents' attitudes and experiences of mobile phones and the internet. CyberPsychology \& Behavior, 7(3), 359-367.

Muhammud, A. (2012). Penghuni Raudhatus Sakinah: Kajian terhadap latar belakang dan faktor salahlaku (Doctoral dissertation, University of Malaya, Kuala Lumpur). Retrieved from http://studentsrepo.um.edu.my/5233/1/AZLINA_BINTI_MUHAMMUD.pdf. 
Ravizza, S. M., Hambrick, D. Z., \& Fenn, K. M. (2014). Non-academic internet use in the classroom is negatively related to classroom learning regardless of intellectual ability. Computers \& Education, 78, 109-114.

Rogers, R. W. (1985). Attitude change and information integration in fear appeals. Psychological Reports, 56(1), 179-182.

Ryan, R., M., \& Deci, E., L. (2000). The darker and brighter sides of human existence: Psychological needs as a unifying concept. Psychological Inquiry, 11(4), 319-338.

Ryan, T., \& Xenos, S. (2011). Who uses Facebook? An investigation into the relationship between the big five, shyness, narcissism, loneliness, and Facebook usage. Computers in Human Behavior, 27, 1658-1664.

Sandstrom, M., Wilen, J., \& Mild, K., H. (2001). Mobile phone use and subjective symptoms. Comparison of symptoms experienced by users of analogue and digital mobile phones. Occupational Medicine, 51(1), 25-35.

Settley, C. (2020). The physical and psychological wellbeing of caregivers of individuals suffering from substance addiction. Archives of Psychiatric Nursing, 34, 107-109.

Sheldon, K., M., Abad, N., \& Hinsch, C. (2011). A two-process view of Facebook use and relatedness need-satisfaction: Disconnection drives use, and connection rewards it. Journal of Personality and Social Psychology, 100(4), 766-775.

Thomee, S., Harenstam, A., \& Hagberg, M. (2011). Mobile phone use and stress, sleep disturbances, and symptoms of depression among young adults-a prospective cohort study. BMC Public Health, 11(66), 1-11.

Wang, Y., Zou, Z., Song, H., Xu, X., Wang, H., d'Oleire Uquillas, F., \& Huang, X. (2016). Altered gray matter volume and white matter integrity in college students with mobile phone dependence. Frontiers in Psychology, 7, 597.

Wang, P., Wang, X., Nie, J., Zeng, P., Liu, K., Wang, J., Lei, L. (2019). Envy and problematic smartphone use: The mediating role of FOMO and the moderating role of student relationship. Personality \& Individual Differences, 146, 136-142.

Walsh, S. P., White, K. M., Hyde, M. K., \& Watson, B. (2008). Dialling and driving: Factors influencing intentions to use a mobile phone while driving. Accident Analysis and Prevention, 40, 18931900.

WhatsApp. (2019). About WhatsApp. Retrieved on 22 October 2020 at https://www.whatsapp.com/ about/. 